\title{
Konstruktivistické a kognitivně-komunikační paradigma jako východisko koncepce výuky českého jazyka ${ }^{1}$
}

\author{
STANISLAV ŠTĚPÁNÍK
}

\begin{abstract}
Abstrakt: Předložená teoretická studie se zabývá problematikou utváření učebního prostředí determinujici kvalitu výuky českého (mateřskébo) jazyka s obledem na integraci sémanticko-logické struktury obsahu propojením jazykové a komunikačni složky predmètu. Nejprve popisuje obecná východiska současného stavu se zvláštním dirazem na vztah oboru (lingvistiky) a školniho predmětu, resp. výuky, analyzuje potiže, které dosavadni pojetí výuky češtiny přináš́, a objasňuje jejich príciny. Na problém se divá z pohledu transdisciplinárni didaktiky i oborové didaktiky českého jazyka. Jako řešení pak predkládá koncepci výuky českého jazyka nazvanou komunikačni nauka o českém jazyku, vymezuje jeji zdroje a stanovuje jeji program.
\end{abstract}

Klíčová slova: transdisciplinárni didaktika, didaktika českého jazyka, český jazyk, koncepce výuky, komunikačni nauka o českém jazyku, konstruktivismus, tradice, inovace.

\section{ÚvoD}

Základní téma transdisciplinární didaktiky a oborových didaktik představuje sblížení hlediska žáka a hlediska vědy, resp. konkrétního vědního oboru, tedy psychodidaktické a ontodidaktické perspektivy (srov. Janík et al., 2013; Slavík et al., 2017). Pohyb mezi těmito dvěma póly je základní náplní práce učitele s obsahem (srov. Janík \& Slavík, 2009, s. 118) - učitel má „nahlédnout a zpracovat obsah výuky jak ze strany nároků oboru, tak s ohledem na nároky žáka“ (Slavík \& Janík, 2005, s. 339).

Učitel mateřského jazyka ${ }^{2}$ je $\mathrm{v}$ tomto směru oproti učitelům jiných předmětů ve specifickém postavení, a to proto, že (1) žáci do školního vzdělávání vstupují vybaveni komplexní praktickou (implicitní)

\footnotetext{
1 Tento text vznikl v rámci projektu PRIMUS/HUM/19 Didaktika českého jazyka v současném vzdélávacím kontextu, financovaného Univerzitou Karlovou a Pedagogickou fakultou Univerzity Karlovy. Autor děkuje za poskytnutou podporu.

2 Úmyslně hovořím o mateřském jazyce, ačkoli mám samožrejmě na mysli primárně český jazyk, protože nastíněné otázky se netýkají jen didaktiky a výuky češtiny, ale lze je považovat za univerzální pro didaktiku a výuku kteréhokoli mateřského jazyka.
} 
znalostí objektu poznání - jazyk ke sdělování významů a porozumění jim užívají každý den - a že (2) objekt poznání je také nástrojem poznání. $\mathrm{Z}$ tohoto pohledu je znalost, jak žáci užívají jazyk a jak o něm přemýšlejí, a zohledňování prekonceptuální výbavy žáků při projektování učebního prostředí, ale i koncepční uvažování o mateřském jazyku jako vyučovacím předmětu jedním ze základních předpokladů kvality ve výuce mateřštiny. Zrovnoprávnění subjektivní a intersubjektivní dimenze obsahu se proto i $\mathrm{v}$ didaktice mateřského jazyka jeví jako zásadní (srov. Štěpáník \& Slavík, 2017).

\section{POHLED TRANSDISCIPLINÁRNí DIDAKTIKY}

Jako stěžejní problém se při utváření učebního prostředí, resp. modelování koncepce vyučovacího předmětu jeví způsob konstrukce vzdělávacího obsahu, jenž v základu vychází z vědního oboru, $\mathrm{k}$ němuž se vyučovací předmět váže. Propojení oboru a výuky - výběr vzdělávacích obsahů i hledání způsobů jejich didaktického uchopení a didaktického zprostředkování žákům - je úkolem oborových didaktik.

$S$ ohledem na propojení psychodidaktického a ontodidaktického pohledu na utváření vyučovacího předmětu, resp. učebního prostředí, uvažuji $\mathrm{v}$ intencích modelu didaktické rekonstrukce, jenž v sobě váže perspektivy žáka, učitele a vědního oboru a zrovnoprávňuje je (Jelemenská, Sander \& Kattmann, 2003; Komorek \& Kattmann, 2008). Didaktická rekonstrukce obsahu je cestou ke zvýšení relevance vzdělávacích obsahů pro žáky, a tedy efektivity vzdělávacího procesu (srov. též Knecht, 2007). Tím se zabraňuje tomu, aby se vyučovací předmět stal pouze zjednodušenou verzí vědního oboru, tedy pouze jakousi oborovou zkratkou. Je vhodné vzpomenout Deweyho myšlenku - pro výuku mateřského jazyka zásadně platnou -, že „obsahy musí být rekonstruovány do zkušeností, z nichž byly abstrahovány" (cit. dle Janík, Maňák \& Knecht, 2009, s. 100). Nebudou-li, stávají se pro žáky prázdnými.

Perspektiva žáků (tj. žákovské prekoncepty obsahu), perspektiva oboru ( $\mathrm{tj}$. vědecké poznání vztahující se k učebnímu obsahu) a vzdělávací prostředí vytvářené procesy vyučování a učení představují v modelu didaktické rekonstrukce vzájemně propojené komponenty. To pro praxi vyvolává trojí potřebu: (1) určit klíčové učební obsahy (tedy základní koncepty a principy poznání), (2) zkoumat žákovské a učitelské perspektivy daného obsahu a (3) dle toho designovat a vyhodnocovat učební prostředí (Duit et al., 2012, s. 13). Didaktická rekonstrukce tak ovlivňuje nejen celkové pojetí a cíle předmětu, ale také výběr obsahu, metod a vůbec způsobu zprostředkování obsahu žákům - tedy celkovou strukturu edukačního prostředí. A právě zde hrají zásadní roli oborové didaktiky jako multidisciplinární obory propojující perspektivy oboru a pedagogických disciplín.

Zásadní obrat v uvažování o obsahu výuky $\mathrm{v}$ modelu didaktické rekonstrukce představuje teze, že oborové aspekty nejsou z didaktického hlediska „ani vůd- 
čí, ani normativní" (Slavík et al., 2017, s. 269). Takový pohled nabourává onu představu školního předmětu český jazyk jako doplňujícího protějšku české lingvistiky (viz dále) a posouvá těžiště obsahově zaměřeného př́stupu od uvažování $\mathrm{v}$ mezích oboru $\mathrm{k}$ uvažování $\mathrm{v}$ mezích komunikačních potřeb žáků jako běžných uživatelů jazyka (avšak pochopitelně stále ve spojitosti s oborem a věrnosti zásadě lingvistického př́stupu - srov. Čechová \& Styblík, 1998, s. 62).

„Z epistemologického hlediska je model didaktické rekonstrukce budován na konstruktivistických základech" (Slavík et al., 2017, s. 269), což je v souladu s moderní produktivní kulturou vyučování a učení, nebot teorie konstruktivismu je v současnosti zásadním zdrojem inovací ve vzdělávání (Janík, 2013; Reich, 2012). Vymezení konstruktivismu $\mathrm{v}$ pedagogice je nezřetelné a spíše než teorií vyučování je teorií učení se (Fosnot, 2005, dle Štěpáník, 2014a). V souladu s Pupalou \& Osuskou (2000, s. 111) konstruktivismus chápu jako „způsob myšlení či uvažování o poznání, jenž může být nápomocný př́i vytváření modelů učení, vyučování a projektování kurikulárních materiálü“. Pro aplikace konstruktivismu ve výuce je třeba hledat konkrétní a ve výuce aplikovatelné principy, na nichž lze stavět edukační prostředí a činnosti uči- tele a žáků v něm. Didaktické implikace konstruktivismu ve výuce češtiny jsem vymezil ve své dřivější práci (viz Štěpáník, 2015), ${ }^{3}$ zde se proto omezím na bod, jenž je podstatný pro následující výklad a jenž z hlediska modelování inovativní koncepce výuky češtiny považuji za ústřední (srov. Štěpáník \& Slavík, 2017): jedním ze základních prvků všech modelů učení vycházejících z konstruktivistických pozic je žákovský prekoncept. Ten lze definovat jako žákovské „předporozumění" obsahu, jako implicitní znalost.

Jazykový prekoncept „představuje určité ,jazykové povědomí jedince, které má složku kognitivní, afektivní a konativní" (Štěpáník \& Slavík, 2017, s. 61). V naší i zahraniční literatuře se hovoří o jazykovém vědomí (language awareness) jako o interiorizovaném systému verbálního chování složeném ze tř́ podsystémů - jazykového, konceptuálního a interakčního (Horecký, 1991, s. 81). Jazykové vědomí lze v tomto smyslu považovat za předpokladovou bázi řeči (Dolník, 2003, s. 2; $\mathrm{k}$ jazykovému vědomí obšírně viz dále).

Rodilý mluvčí vstupuje $\mathrm{v} 1$. ročníku základní školy do výuky s výbavou kvalitativně blízkou řeči dospělého člověka (Jelínek, 1980, s. 32; srov. též Gombert, 1992, či Průcha, 2011). Právě proto je třeba žákovský prekoncept posunout do středu veškerého didaktického uvažování

\footnotetext{
3 Ve zmíněné studii jsem jako základní charakteristiky konstruktivisticky pojaté výuky uvedl následující body: Konstruktivistická výuka (1) znamená aktivní konstrukci znalostí; (2) počítá s dosavadním poznáním žáků, aktivně ho využívá a dále s ním pracuje; (3) hledá a oceňuje perspektivu žáků; (4) pracuje s velkými celky, nikoli $s$ detaily; (5) klade důraz na relevanci učiva pro žáky z hlediska jejich každodenní zkušenosti, zařazuje učivo do kontextu světa; (6) využívá komplexní a longitudinální hodnocení. Rozpracování jednotlivých bodů a další didaktické implikace konstruktivismu pro praxi výuky českého jazyka viz v odkazovaném textu.
} 
o obsahu výuky mateřského jazyka a způsobu jeho didaktického zprostředkování, a učinit tak z prekonceptu konstitutivní element modelování koncepce výuky (Štěpáník \& Slavík, 2017, s. 59).

Základní determinantou výukového procesu je učitel a jeho osobnostní i profesní charakteristiky. Aby byl učitel schopen zajistit vysokou kvalitu výuky, potřebuje disponovat nejen dobrou znalostí obsahu, ale rovněž si uvědomovat jeho didaktický potenciál - hovoříme o didaktické znalosti obsahu (pedagogical content knowledge - Shulman, 1987). Didaktická znalost obsahu zahrnuje (a) znalost vyučovaného obsahu, (b) pedagogické znalosti a dovednosti a (c) znalost dispozic žáků (srov. Metz, 2018), jinými slovy znalost obsahu a dovednost přizpůsobit způsob didaktického zprostředkování obsahu konkrétní skupině žáků, ev. konkrétnímu žákovi (srov. též Duit et al., 2012, s. 28).

Jsou-li základními komponentami modelu didaktické rekonstrukce žákovská, učitelská a oborová pojetí obsahu, pak existuje blízký vztah mezi obsahem a učitelovým didaktickým uchopováním obsahu, nebot to rovněž zohledňuje perspektivy žáka, učitele a oboru (srov. též van Dijk \& Kattmann, 2007). Učitelovo uvažování o obsahu se tak stává jedním ze zdrojů projektování učebního prostředí, což má dalekosáhlé důsledky mj. pro způsob př́ípravy učitelů.

\section{PoHLED OBOROVÉ DIDAKTIKY MATEŘSKÉHO JAZYKA}

Pro předmět český jazyk je základním mateřským oborem lingvistika. Ta v prů- běhu vývoje vyučování češtině vždy hrála v utváření podoby předmětu český jazyk klíčovou roli, a to jak z hlediska vědeckých př́stupů k jazyku, tak i osobnostmi, které do vývoje lingvistiky a oborové didaktiky češtiny vstupovaly a vstupují (srov. Šmejkalová, 2010, 2015; autorka didaktiku českého jazyka nazývá „pandánem“ k vývoji české lingvistiky - osobní rozhovor). Důsledkem tohoto úzkého propojení oboru a oborové didaktiky je utváření učebního prostředí metodologií lingvistiky (Štěpáník, 2019a, s. 13), čímž se vědecká lingvistika do předmětu český jazyk a praxe jeho výuky transformuje do podoby „malé lingvistiky“, tj. jakési zjednodušené verze oboru, která je didaktizována nikoli směrem $\mathrm{k}$ rozvoji komunikace a jazykového myšlení, jak by bylo žádoucí, ale k rozvoji cílů formálně-poznávacích (v podstatě myšlení o jazyce). Cílem i obsahem stávající výuky tak je do určité míry didaktizované zprostředkování lingvistických teorií namísto rozvoje komunikačních dovedností žáků o lingvistické teorie opřené. Hovoříme o výuce tradiční školské mluvnice (srov. Palek, 1989, s. 245). Tato zjednodušená verze oboru však didaktickým cílům nevyhovuje, o čemž svědčí problémy výuky a její nedostatečné výsledky, reflektované průběžně a opakovaně v odborné literatuře a $\mathrm{v}$ poslední době také $\mathrm{v}$ mainstreamových médiích (o tom, že se výuka českého jazyka nachází v permanentní krizi, se v didaktice češtiny hovoří dlouhodobě - srov. např. Šmejkalová, 2010, či prríspěvky v časopisu Český jazyk a literatura; problémy komplexně shrnuty in Štěpáník \& Slavík, 2017, s. 66; Štěpáník, 2019a, s. 11). 
Tím však výuka mateřštiny v naší škole ztrácí smysl a padá do formalismu, nebot cílem se stává poznání jazykového systému samo o sobě, zatímco reálně by poznatky o fungování jazyka měly sloužit rozvoji komunikačních dovedností a kognitivních schopností žáka. Principiálně je kompetenční cíl poznávacímu cíli nadřazen (srov. obsah kurikula, ale též teze oborové didaktiky češtiny - srov. např. Čechová, 1998; Čechová \& Styblík, 1998; Hájková, 2009; Svobodová, 2003; Šebesta, 2005; Štěpáník \& Šmejkalová, 2017; Štěpáník, 2019b, ad.). To znamená, že učivo samo o sobě není cílem výuky, nýbrž prostřredkem $\mathrm{k}$ dosažení skutečných cílů. Praxe však tomuto základnímu postulátu neodpovídá. Namísto něj z různých důvodů utváŕí určitý vlastní systém cílů a postupů, čímž je dlouhodobě od teorie vzdálená, resp. se jí dále vzdaluje.

$\mathrm{Na}$ přelomu 60. a 70. let došlo v lingvistice ke komunikačně-pragmatické$\mathrm{mu}$ obratu, čímž se pozornost lingvistů koncentrovala na „fungování jazyka v konkrétních komunikačních situacích a na pragmatické aspekty, které komunikační situace doprovázejí" (Šmejkalová, 2010, s. 369). Pod tímto vlivem komunikačně-pragmaticko-sémantická orientace pronikla také do didaktiky cizích a mateřských jazyků, jazyková výchova se ve vzrůstající míre orientovala komunikačně, posiloval se sémantický a funkční princip a komunikační zřetel se postupně stal určujícím principem lingvodidaktiky (Šmejkalová, 2010, s. 369; k vývojovým otázkám v didaktice češtiny srov. Šmejkalová, 2010, 2015; vývoj s akcentací komunikačního principu viz Štěpáník, Liptáková \& Szymańska, 2019).

Vlivem popsaných změn však došlo ke dvojí tenzi: (a) mezi oborovou didaktikou českého jazyka a pedagogickou praxí (zatímco oborově didaktické uvažování zdůrazňuje komunikační cíle, školní vyučování většinově setrvává na pozici cílů formálně-poznávacích); (b) mezi složkou jazykovou a komunikačnít předmětu český jazyk a literatura, resp. mezi zacílením na rozvoj jazykových znalostí (v současné praxi znalostí o jazyce) a na rozvoj komunikačních dovedností.

Ad a) $Z$ různých dokladů (napŕ. Chvál \& Šmejkalová, 2018; Kotenová, 2018/2019; Pavelková, 2013; Šalamounová, 2013, 2015; Štěpáník, 2016, ad.) a z hojného pozorování pedagogické praxe, jež bylo předmětem projektu, jemuž je dedikován tento text, lze vyvodit, že převažujícím př́istupem v edukační realitě českého jazyka je tradiční model vyučování, který lze postihnout následujícími charakteristikami:

- Učivo odráží vědeckou strukturu lingvistiky jako mateřského oboru, základním východiskem pro uspořádání učiva jsou jednotlivé jazykové disciplíny z oblasti langue.

- Osvojované znalosti mají terminologicko-definiční povahu.

- Primárním postupem je dedukce a metoda analyticko-syntetická; jazykové jevy ve výuce fungují jako abstrakce

\footnotetext{
4 Označení komunikační, komunikačně-slohová či slohová (složka) chápu v tomto textu jako úplná synonyma.
} 
$\mathrm{k}$ rozboru, aniž by byly jakkoli zasazeny do komunikačního kontextu.

- Hlavní didaktickou strategií je frontální vyučování a tradiční transmisivně-instruktivní model řízení učebních činností žáků.

- U poznatků se nehledá jejich funkce v komunikaci, v poznávání jazyka absentuje pragmaticko-sémantický a obecně komunikační přesah.

- Primárně sledovaný cíl je cíl kognitivní, v konečném důsledku však omezovaný pouze na cíl formálně-poznávací (jako argument pro zařazování mluvnického učiva do vyučování češtině se často uvádí rozvoj myšlení žáka - vychází se zde z úzkého vztahu jazyka a myšlení - srov. např. Jelínek, 1980).

- K osvojování metajazyka dochází spíše pro metajazyk sám, než aby měl nějaké další využití.

Popsaný model lze označit jako systémově-gramatický (Nocoń, 2010, s. 28) nebo též gramaticko-normativní (Nocoń, 2018, s. 115). Preskriptivní charakter jazykového vyučování (v užším smyslu mluvnice) má za následek asociování jakýchkoli jazykových pravidel $s$ predstavou chyby a (ne)správnosti, celkově má spíše nega- tivní konotace (srov. Myhill, 2005, s. 78). Zásadní je v tomto ohledu fenomén jazykového sebevědomí uživatele jazyka (viz Dolník, 2003), které lze definovat jako jazykové a metajazykové reakce vyvolané tlakem na uživatele jazyka při uplatňování jazykového vědomí (tamtéž, s. 2); jinými slovy jako ,jistotu v jazykovém a metajazykovém chování, která závisí na sebereflexi ve vztahu k ovládání jazyka, na vnímání hodnoty jazyka a na přesvědčení o imunitě jazyka“5 (tamtéž, s. 6).

Reflexe a hodnocení vlastního jazykového vědomí (tj. užívání jazyka v komunikaci) se odráží v úrovni jazykového sebevědomí (Dolník, 2003, s. 2). ${ }^{6}$ Nejistota při užívání jazyka plyne z povahy jazykového systému (např. dubletní tvary, paronyma, přechody sloves mezi slovesnými třídami, problémy jmenného rodu), $\mathrm{k}$ narušení jazykového sebevědomí však může vést i nevhodně pojaté jazykové vyučování, které sice směřuje ke zdokonalení jazykového vědomí uživatelů jazyka (srov. definici dále) a kultivování jejich jazykových dovedností, avšak svým preskriptivním, normativním, formálním a tradičně kritickým přístupem „celkově působí proti reprodukci normálního jazykového sebe-

5 Tím má autor na mysli asimilačně-akomodační rovnováhu jazykového systému a pružnost a stabilitu jazykové normy.

${ }^{6}$ Jako př́íklad uved’me výukovou situaci, jižž byla svědkem G. Babušová, didaktička českého jazyka pro 1. stupeň ZŠ. Učitelka ve 4. ročníku ZŠ zadala žákủm, aby navrhli slova s předponami či př́ponami k základu let. Jeden z žáků navrhl slovo předlet, které učitelka zprvu zamítla s tím, že takové slovo neexistuje. Když však zpozorovala nesouhlasnou reakci hospitující Babušové, požádala žáka o vysvětlení významu daného slova. Žák navrhl hned dva: bud' se jedná o stav, kdy letadlo ve vzduchu předletí jiné letadlo, anebo kdy letadlo, které mělo vzlétnout z letiště jako druhé, dostane pokyn z řídicí věže, aby „předletělo“ “jiné letadlo také čekající na odlet, jež však mělo vzlétnout jako první. „Jazykové výtvory tohoto druhu nejsou svědectvím deficitu v ovládání jazyka, jak se to jeví ze stanoviska klasického systémovolingvistického myslitele, ale manifestováním přirozeného ovládání jazyka, při kterém se analogie spojuje i s interpretací, která se opírá o fikci a imaginaci“ (Dolník, 2003, s. 4). 
vědomi“" (tamtéž, s. 11), čímž ho podrývá. „Narušené přirozené jazykové sebevědomí si vyžaduje oporu (jazykové ,tutorství) a zabraňuje tomu, aby uživatel vnímal sebe jako rovnocenného člena jazykového společenství, který spolu s ostatními členy ,rozhoduje‘ o vlastním jazyku. V jazykové praxi se tato závislost projevuje $\mathrm{v}$ jazykovopsychickém napětí (,Co zase řeknu/ napíšu špatně?'), ${ }^{7}$ které omezuje normální uplatnění jazykových prostředků individuálního jazykového vědomí, jakož i v pasivním, ba ,pokorném přijímání kritiky bez vyvíjení úsilí o reflexi svého jazykového výtvoru" (Dolník, 2003, s. 11-12; srov. též Smith, Cheville \& Hillocks, 2006). Kromě toho má narušené přirozené jazykové sebevědomí také za následek „otupení [...] (prožívaného) vztahu $\mathrm{k}$ vlastní jazykové kompetenci, umrtvuje prožívání normálnosti této kompetence", vede $\mathrm{k}$,jazykovému pseudosebevědomí “ (tamtéž, s. 12) a závislosti na autoritě (tamtéž, s. 11). Dominance tohoto pojetí školní výuky se pak odráží také ve způsobu uvažování široké veřejnosti o jazyku a jazykové normě. ${ }^{8}$
Ad b) Ačkoli by měly být jazyková a komunikační složka komplementární, nebot' z podstaty nelze oddělit jazyk od jazykové komunikace a jazykovou komunikaci od jazyka, ve školní praxi výuky českého jazyka $\mathrm{v}$ drtivé většině vystupují odděleně (srov. učebnice nebo rozvrhy vyučovacích hodin žáků v české škole). Příčinou je jednak nepropojení ontodidaktické a psychodidaktické perspektivy - intersubjektivní dimenze obsahu výuky se odděluje od dimenze subjektivní (srov. Janík \& Slavík, 2009) - a jednak dezintegrace sémanticko-logické struktury obsahu výuky (Slavík et al., 2017, s. 322n.) českého jazyka, čehož důsledkem je právě popsané nesmyslné separování jazyka od komunikace. Cíle výuky českého jazyka tak zůstávají nenaplněny.

Základní téma oborové didaktiky českého jazyka (a mnoha dalších mateřských jazyků) tak představuje vztah výuky jazyka a o jazyce (v užším smyslu mluvnice) a rozvoje komunikačních dovedností žáka (srov. Štěpáník et al., 2019). Tento okruh problémů zasahuje do obsahu výuky, způsobů jeho didaktického uchopování a vůbec

\footnotetext{
S takovými pochybnostmi se lze mezi rodilými mluvčími češtiny setkat často. Zaměříme-li se však na školní praxi, důležitou roli hraje mj. napětí mezi situací hodnoceného výkonu (zkoušky) a požadavky výchovně-vzdělávacích cílů. Jako typický príklad pro výuku češtiny lze uvést slohové práce: na jedné straně by měla školní výuka vést $\mathrm{k}$ rozvoji jazykové kreativity, a tudíž by měla oceňovat kreativní, osobitá, originální slohová řešení ve vyjádření žáků, na druhé straně existuje riziko „chyby“ či nedostatku ve složitějšśi (chceme-li, nápaditější, tvořivější) jazykové struktuře, což však následně může zhoršit výsledek hodnocení. Žáci proto mohou být vedeni $\mathrm{k}$ jednodušším a „méně riskantním“ řešením (srov. nap̌̌. nabádání učitelů $\mathrm{k}$ výběru témat $\mathrm{v}$ rámci maturitní zkoušky - Štěpáník, 2018). Tento rozpor se poté projevuje také u mluvčích, kteří již školu (dávno) absolvovali. 8 Svědectví o tom podávají pracovníci Jazykové poradny Ústavu pro jazyk český AV ČR, jejichž odpovědi na dotazy mají primárně charakter výkladu problému a př́ípadných doporučení (význam slova doporučeni je zásadní). S tím se ovšem nemálo uživatelů nechce smírit a očekává, že Poradna poskytne odpověd”, „co je správně“ a „jak to teda má být“. Jazyk je viděn jako cosi statického, neměnného, nepružného, na ose správné - nesprávné (mnohdy zjednodušeně vnímané také jako osa spisovné - nespisovné), namísto adekvátní (funkční) - neadekvátni (nefunkčni).
} 
smysluplnosti výuky, tedy její celkové cílové orientace.

V oborové didaktice češtiny lze v poslední době pozorovat určitý badatelský deficit způsobů utváření a kvality učebního prostředí $\mathrm{v}$ předmětu český jazyk. Dochází k tomu, co Slavík et al. (2017, s. 310n.) vystihují jako „badatelskou rezignaci na zkoumání kvalit učebního prostředí“: zkoumány (a kriticky hodnoceny) jsou především vzdělávací efekty výuky, př́íp. se didaktika češtiny zabývá řešením metod nebo obsahu, avšak v nadměrném vzájemném oddělení (srov. odtrhování obsahu od metod jako zdroj didaktických formalismů in Slavík et al., 2017, s. 311).

I z tohoto důvodu sílí zpochybňování důležitosti či samé podstaty explicitní výuky mateřského jazyka (mluvnice) v české škole (srov. Čechová, 2011/12; Zimová, 2011/12; téma se stává celospolečenským - srov. shrnutí mediálních diskusí in Štěpáník \& Šmejkalová, 2017). ${ }^{9}$ Příčinou je, že dosavadní obsah předmětu český jazyk (tj. př̀evážně bázové lingvistické disciplíny $\mathrm{z}$ roviny langue) a především způsob jeho didaktického zprostředkování žákům nepřinášejí očekávané výsledky ${ }^{10}$ a nevyhovují aktuálním komunikačním potřebám žáků. ${ }^{11}$ Shrnuto: opomíjením aktuálního kulturně-sociálního, zvláště komunikačního kontextu a odcizením od faktických potřeb žáků se explicitní výuka češtiny (její mluvnice) jeví jako zbytečná, až nesmyslná.

Především je pomíjen nesmírně dynamický rozvoj technologií, jenž zásadně mění způsob komunikace - pozorujeme expanzi mluvenosti do všech komunikačních sfér (Čmejrková \& Hoffmannová, 2011; Hoffmannová et al., 2016), nástup a v některých oblastech dominanci komunikace jinými kódy než kódem jazykovým, rozvolňování norem, benevolenci (jazykového) chování (srov. Nocoń, 2018, s. 25n.), demokratizaci jazyka a integrování prvků z jiných variet do variety spisovné (Svobodová et al., 2011, s. 11) atd. Že obsah výuky zůstává stabilní, ${ }^{12}$ je na jednu stranu dobře, nebot́ to chrání výuku před jejími neuváženými proměnami a bezúčelnou honbou za vzdělávacími novinkami. $\mathrm{Na}$ druhou stranu to však upevňuje anachronický obraz světa (Nocoń, 2018, s. 29).

Se stoprocentní jistotou však můžeme říci, že výše naznačený vývoj není jen krátkodobá záležitost, která se postup-

\footnotetext{
9 Identický problém popisuje Nocońová (2018) ve výuce polštiny, byt z některých jiných důvodů než v české situaci; podobné diskuse lze pozorovat i jinde ve světě.

${ }^{10}$ Srov. např̀. nejnovější zprávu České školní inspekce k rozvoji čtenářské gramotnosti na základních a středních školách, která poukazuje na závažné deficity žáků ve zkoumané oblasti (ČŠI, 2019). Znalosti o fungování jazyka jsou přitom předpokladem $\mathrm{k}$ efektivnímu porozumění textu; neblahé důsledky separování jazykové a komunikační složky jsou tedy ve výsledcích zmíněné zprávy evidentní.

${ }^{11}$ „[...] učitelská generace (a také jiní další školení odborníci zabývající se profesně češtinou) výrazně více lpí na původních zvyklostech a ohližení se do minulosti a drží se tradičních, ba tradicionalistických představ" (Svobodová et al., 2011, s. 14). Svobodová (2003, s. 56) hovoří o „hyperkorektnosti ve školském pojeti'“.

12 Školská gramatika v české škole se opírá o řeckou a římskou (latinskou) tradici a ve své podstatě se neliší od Priscianovy gramatiky z 6. stol. n. l. (Palek, 1989, s. 245).
} 
ně vrátí do původního stavu, nýbrž jde o trvalý posun $\mathrm{v}$ mezilidské komunikaci, jenž naopak bude dále postupovat. Jako takový jej obsah výuky češtiny ve škole 21. století nemůže ignorovat a bylo by zhola zbytečné, aby s ním bojoval - žáci se každodenně v této komunikační realitě pohybují, jsou její součástí, dokonce ji sami utvářejí a přispívají $\mathrm{k}$ jejím pohybům. Komunikují v nových prostředích a novými způsoby, komunikáty nejen vytvářejí, ale také recipují, což obojí vyžaduje specifické znalosti a dovednosti, jež doposud součástí obsahu výuky nejsou. Některé z dovedností - např. odhalování manipulace $\mathrm{v}$ komunikaci nebo dovednost přepínání kódu - se v kontextu dnešního světa jeví pro fungování mladého člověka ve společnosti jako naprosto klíčové. $\mathrm{K}$ popsaným proměnám se pochopitelně dále přidružují změny na trhu práce, celková změna fungování ekonomiky a běhu společenského života atd. Nový kulturně-komunikační stav, a tedy nové kontexty a nové podmínky výuky mateřštiny je třeba chápat jako přirozený proces (srov. Nocoń, 2018).

Pochybnosti o významu jazykové výuky v mateřském jazyce jsou soustředěny kolem jedné centrální otázky: Je treba vyučovat něco, co dítě prirrozenè ovládá? A př́padně proč? Existují hlasy, které explicitní výuku mluvnice zcela odmítají a říkají, že by se jazyk měl u žáků rozvíjet cvikem, nápodobou, v podstatě agramaticky (agramatické hnutí se v historii objevilo - u nás na přelomu 19. a 20. století - a bylo překonáno jako nefunkční srov. Jelínek, 1972, a Šmejkalová, 2010). Rozhodně nejde o problém ryze český, cesty ke komunikační funkcionalizaci výuky jazyka (v užším smyslu mluvnice) proponují didaktiky mateřských jazyků v mnoha zemích světa (srov. Štěpáník et al., 2019), stejně tak v řadě vzdělávacích systémů pozorujeme popsanou disparátnost mezi oborovou didaktikou a výukovou praxí.

$\mathrm{Na}$ rozdíl od českého prostředí, $\mathrm{v}$ němž máme $\mathrm{k}$ dispozici zatím pouze parciální studie o (ne)funkčnosti tradiční koncepce výuky mateřského jazyka, v zahraničí již komplexní výzkumy efektivity různých způsobů výuky mluvnice ve vztahu $\mathrm{k}$ rozvoji komunikačních dovedností žáků provedeny byly (většina zkoumá odraz v rozvoji dovednosti psaní; ${ }^{13}$ komplexně srov. Klimovič, 2019; nejzásadnější studie např. Andrews et al., 2006; Jones, Myhill \& Bailey, 2013; Myhill, 2018; Wyse, 2001). Z nich vyplývá, že doposud žádná studie jakoukoli efektivitu tradičního mluvnického vyučování směrem $k$ rozvoji komunikačních dovedností žáků neprokázala, některé studie tradiční mluvnické vyučování označují za škodlivé (k výseči českého kontextu srov. např. Hájková, 2013). Jak upozorňuje Myhillová, „neexistuje žádný logický, kognitivní ani edukační důvod, proč by dovednost pojmenovat a určit jazykové gramatické struktury

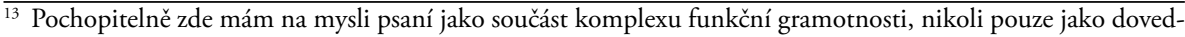
nost graficky zaznamenávat text.
} 
měla jakkoli zlepšovat dovednost psaní “14 (Myhill, 2018, s. 3).

Avšak i pokud implicitní znalost funguje, je třeba ji činit explicitní, nebot právě explicitní znalost umožňuje „reflexi, ověřování, analýzu a reorganizaci produktů implicitního učení“ (Liptáková, 2013, s. 19) a je „více kognitivně přístupná užití “ (Myhill, 2005, s. 89), čímž se stává podstatným nástrojem pro uživatele jazyka při komunikaci. ${ }^{15}$ Velké výzkumy právě D. Myhillové a také studie dalších expertů ukazují, že explicitní výuka mluvnice pozitivní vliv na rozvoj komunikačních dovedností žáka má (srov. Myhill, 2016, 2018; Myhill et al., 2012; Derewianka \& Jones, 2010; Fearn \& Farnan, 2007; Fogel \& Ehri, 2000; v českém prostředí Štěpáník \& Chvál, 2016; nejvíce studií se věnuje rozvoji dovednosti psaní, některé i dovednosti čtení).

Základním východiskem mého veškerého uvažování o jazykové výuce proto je, že explicitní výuka jazyka a o jazyku (v užším smyslu mluvnice) význam má, ale je třeba hledat a do praxe implementovat efektivní přemýšlení o jejím obsahu a funkční postupy jeho zprostředkování žákům. Nestojíme tedy před otázkou, zda vůbec mluvnici vyučovat, nýbrž jakým způsobem ji vyučovat.

\section{ROZVOJ JAZYKOVÉHO VĚDOMÍ JAKO ZÁKLADNÍ CÍL VÝUKY MATEŘSKÉHO JAZYKA}

Již jsme řekli, že dítě-rodilý mluvčí přirozeně nabývá mateřského jazyka a dorozumívá se s jinými mluvčími. Jeho znalost je implicitní (neuvědomělá/tacitní). ${ }^{16}$ Nedisponuje aparátem ke zdůvodňování volby jazykových prostředků sobě a ostatním či $\mathrm{k}$ vědomému výběru takových prostředků, které by lépe sloužily ke splnění jeho komunikačního záměru; $\mathrm{z}$ toho důvodu se může dopouštět nedostatků ve výběru jazykových prostředků vzhledem ke komunikační situaci, ke komunikačnímu partnerovi a ke svému komunikačnímu záměru. Úkolem školy je vypěstovat z žáka člověka komunikačně kompetentního, tj. takového, který je schopen z možností jazykového systému vědomě vybírat ty jazykové prostředky, které nejlépe slouží jeho komunikačnímu záměru a jsou adekvátní komunikační situaci, a svou volbu sobě či ostatním zdůvodnit. Podmínkou komunikační kompetence je přitom ovládnutí kompetence jazykové. Ta je založena na jazykových znalostech (srov. Dolník, 2005, s. 41),

\footnotetext{
${ }_{14}$ Psaní lze považovat za jednu z nejkomplexnějších aktivit, kterou žáci ve výuce vykonávají, nebot vyžaduje zapojení složitých a rozmanitých kognitivních procesů a rovněž využití sociálních a jazykových dovedností a znalostí (Myhill et al., 2011, 2012; Klimovič, 2016). Výsledky lze proto považovat za vysoce relevantní k významu mluvnice ve výuce mateřského jazyka obecně a lze je vztáhnout i na rozvoj ostatních komunikačních dovedností (tj. mluvení, naslouchání a čtení).

${ }^{15}$ Ve shodě s Liptákovou (2013, s. 18) chápu implicitní učení jako proces přirozený a neuvědomovaný, zatímco explicitní učení jako proces uvědomovaný (viz též dále). Mezi implicitními a explicitními jazykovými znalostmi probíhá dynamická interakce (tamtéž).

${ }^{16}$ Při vědomí možností různých definic zmíněných termínů je zde užívám jako synonymní, nebot svou základní definicí všechny odpovídají prekonceptuální výbavě žáka.
} 
čímž se zakládá důvod $\mathrm{k}$ explicitní výuce jazyka a o jazyce. Shrnuto: úkolem školy je převést implicitní znalost na znalost explicitní, uvědomělou.

Z psychodidaktického pohledu lze $\mathrm{v}$ tomto směru hovořit o rozvoji jazykového védomi $i^{17}$ (language awareness - srov. např. Dolník, 2003; Gombert, 1992; Horecký, 1991; Myhill, 2005; Svalberg, 2007, ad.). Jeho obsahem je „systém verbálního chování a systém hodnocení, formou je banka dat $s$ prŕslušnými pomocnými subsystémy, resp. sít výrazových kategorií a normativních hledisek" (Horecký, 1991, s. 85$).{ }^{18}$ Zahrnuje (1) znalost jazykového prostřredku, (2) uvědomování si možnosti výběru, a (3) dovednost uskutečnění výběru (srov. též Dyduchowa, 1988, s. 10). $\mathrm{V}$ tomto smyslu se tak složky jazykového prekonceptu - (a) složka kognitivní, (b) složka afektivní a (c) složka konativní (Štěpáník \& Slavík, 2017, s. 61) - obohacují a rozvíjejí v mezích příslušného konceptu, nebot složky jazykového vědomí korelují se složkami jazykového konceptu poznávaného jednak v lingvistice, jednak v komunikační praxi (rodilých mluvčích). $\mathrm{V}$ průběhu výuky - ale též komunikační praxe, nebot ta je rovněž (základním) zdrojem pozná(vá)ní jazykových konceptů - pak dochází $\mathrm{k}$ tř́ibení prekonceptu, přičemž koncept funguje jako konstrukt, podmínkou jehož reálného zvládání je neustálé ověřování kvalit jazykového jednání v aktuálních situacích (at' už ve výuce či v reálné komunikaci), včetně ověřování závislého na poznatcích lingvistiky. Proto hovoříme o poučeném a později kultivovaném jazykovém vědomí (spontánní jazykové vědomí se postupně proměňuje; srov. Horecký, 1991, s. 87; Liptáková et al., 2011, s. 22-23). Poučené jazykové vědomí tak můžeme definovat jako souhrn představ, zkušeností a poznatků o struktuře jazyka, o jeho jednotkách a pravidlech, ale též souhrn schopností rozlišit adekvátnost užití daného jazykového prostředku v dané komunikační situaci a s daným komunikačním záměrem (dle Horeckého, 1991), jinými slovy dovednost spojovat jazykový prostředek s jeho funkcí a s jeho komunikačním účinkem na adresáta. Tím se explicitní jazyková výuka stává prostředkem propojení implicitních a explicitních znalostí, tedy spojnicí mezi prekonceptem a konceptem. Spontánní jazykové vědomí se totiž pohybuje především na úrovni prekonceptuální, zatímco mluvčí s poučeným jazykovým vědomím se $\mathrm{v}$ podstatě dostává na úroveň konceptuální, přičemž tento vztah nechápu dichotomicky, ale spíše jako kontinuum. $\mathrm{Z}$ doposud uvedeného evidentně vyplývá, že pokud má dojít $\mathrm{k}$ naplnění zmíněných

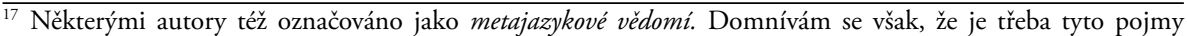
odlišit: jazykové myšlení vede k rozvoji jazykového vědomí, jazykovědné (metajazykové) myšlení vede k rozvoji jazykovědného (metajazykového) vědomí (srov. Bakuła, 2014, s. 39).

${ }^{18}$ Jak Horecký (1991) upozorňuje, jazykové vědomí netvoří jen složka jazyková, nýbrž i složka axiologická (hodnotící), která se projevuje nejen na ose správně - nesprávně z hlediska normy a kodifikace, ale primárně z hlediska vhodnosti/přiměrenosti ke komunikačnímu zámèru mluvčiho. Právě rozvoj axiologické složky tímto směrem představuje významnou změnu kvality výuky českého jazyka.
} 
cílů, není možné, aby byla výuka mateřštiny pojata tradičně - logicko-gramaticky a dezintegrovaně (srov. výše).

V jistém smyslu lze jazykové vědomí ztotožnit s vymezením komunikační kompetence, jež bývá někdy široce chápána jako „soubor všech mentálních předpokladů, které člověka činí schopným komunikovat" (Šebesta, 2005, s. 60). Avšak skutečně komunikačně kompetentní je pouze ten, kdo je schopen vybírat takové jazykové prostředky, jež nejlépe vyhovují komunikační situaci a naplnění komunikačního záměru mluvčího - kdo disponuje poučeným jazykovým vědomím.

Disponuje-li uživatel jazyka poučeným jazykovým vědomím, tedy je-li vskutku komunikačně kompetentní, jeho soubor mentálních předpokladů lze definovat jako komplex různých kompetencí:

a) kompetence jazykové (dovednost rozumět a produkovat nekonečné množství výpovědí, s nimiž se uživatel jazyka doposud nesetkal),

b) kompetence sociolingvistické (dovednost přepínání kódu dle komunikační situace, komunikačního partnera a komunikačního záměru),

c) kompetence sociokulturní (dovednost využívat $\mathrm{v}$ konstrukci i interpretaci komunikátů kulturního kontextu),

d) kompetence jazykovědné (dovednost jazyk reflektovat, uvažovat o něm, znalost metajazyka),

e) kompetence diskursivní (dovednost tvořit komunikáty s využitím různých jazykových prostředků adekvátní pro různé komunikační situace; dle Szymańské, 2016, s. 181).

V tomto smyslu tedy chápu základní cíl jazykové výuky jako prohlubování a rozšiřování jazykového vědomí, tj. rozvoj poučeného jazykového vědomí žáka (srov. Liptáková et al., 2011, s. 22-23, 94). Ten nastává pod vlivem školní jazykové edukace, rozvíjí se zejména na základní škole, prohlubuje se na střední škole a postupně se dostává na úroveň standardního (běžného, každodenního) jazykového vědomí (srov. Horecký, 1991, s. 87). V rozvoji poučeného jazykového vědomí žáka jako hlavním cíli jazykové výuky se střetávají všechny tř̌i základní cíle jazykové výuky: cíl komunikační, kognitivní i formativní (srov. Čechová \& Styblík, 1998, s. 10). K jejich naplňování dochází rozvojem bázových komunikačních dovedností, tj. psaní, mluvení, naslouchání a čtení a s ohledem na moderní kontexty zmíněné výše také nahližženi19 (překlad S. Š., v orig. viewing - srov. obsah australského kurikula).

Převedení hlavního cíle jazykového vyučování češtiny od „rozvoje schopnosti komunikace spisovným jazykem" (Čechová \& Styblík, 1998, s. 10) k rozvoji poučeného jazykového vědomí znamená posun k poznávání možností, které pro komunikaci různých záměrů a významů uživateli systém českého jazyka dává. Výsledkem kultivovaného jazykového vědomí je dovednost strídání kódu (code alteration nebo code switching), již lze definovat

\footnotetext{
${ }^{19}$ Jde o dovednost recipovat tzv. složené komunikáty, tj. takové, které využívají míšení sdělovacích kódů (obraz a psaný či mluvený text, hudba atd. - typicky statusy na sociálních sítích, blogy, vlogy apod.).
} 
jako „jazykové chování, při kterém mluvčí (opakovaně) přechází z jednoho kódu (variety) jazyka do jiného a nazpět" (Čermák, 2004, s. 286). Spisovný jazyk jako kód reprezentativní, celonárodní a prestižní zůstává středobodem, $\mathrm{k}$ němuž se všechny další jazykové vrstvy vztahují, nicméně mizí dosavadní tendence $\mathrm{k}$ dichotomii na správné a chybné, dobré a špatné (srov. pozn. 18). $Z$ didaktického pohledu jsou všechny útvary českého jazyka, jež žáci používají, chápány jako rovnoprávné, přičemž výuka důsledně respektuje funkční rozvrstvení jazykových projevů žáků a žáky $\mathrm{k}$ poznání funkčního rozvrstvení vede. Žákův přirozený kód je třeba vnímat jako plnohodnotný komunikační prostřredek s cílem nikoli jej vykořenit, nýbrž stávající výbavu žáka rozvinout, kultivovat a zvědomnit její formální i funkční kvality, tj. její možnosti a limity. Základním účelem poznávání jazyka, tj. školní výuky jazyka, se tak stává ,znovuobjevování jazyka“" (Höflerová, 2015, s. 534), jakési rozkrývání/objevování jazykových jevů $\mathrm{v}$ jejich komunikačním kontextu, odhalování jejich sémantických, pragmatických, funkčních, kognitivních, sociolingvistických a diskursivních kontextů. Takový pohled umožňuje uvidět význam výuky o jazyku (v užším smyslu mluvnice) a tím zároveň stanovuje podmínky smysluplnosti její výuky.

Explicitní výuka mluvnice má žákovi poskytnout poznání vlastností jazykových prostředků vzhledem $\mathrm{k}$ jejich funkci v komunikaci, tzn. že různé funkce a myšlenky mohou být vyjádřeny různými jazykovými formami (vztah významu a for- my), s čímž úzce souvisí zafixování takové znalosti dostupným a lehce manipulovatelným metajazykem (srov. Derewianka \& Jones, 2010, s. 6), jenž žákovi umožňuje o jazyce uvažovat, reflektovat jej a jazykové volby především sobě, ale i ostatním uživatelům jazyka osvětlovat a zdůvodňovat (srov. Štěpáník \& Slavík, 2017). Tím se mluvnice a její výuka stávají nástrojem ke zlepšení komunikace.

\section{KOMUNIKAČNÍ NAUKA \\ O ČESKÉM JAZYKU}

Jak jsem právě demonstroval, jazykové vědomí je struktura značně komplexní, což se nutně musí projevit také $\mathrm{v}$ praxi výuky. Základním předpokladem pro rozvoj poučeného jazykového vědomí žáka je konstrukce učebního prostředí, které dodržuje sémanticko-logickou strukturu obsahu tak, že jazykové učivo (jazykové koncepty) chápe jako prostředek $\mathrm{k}$ rozvoji kompetencí, nikoli jako obsah per se, jak je tomu v prrípadě oddělení poznávání jazyka a o jazyku od komunikace, a že navazuje na implicitní znalosti, jimiž žáci ve výuce disponují (srov. model hloubkové struktury výuky jako reprezentaci integrity výuky in Slavík et al., 2017, s. 341n.). Principiálním příznakem integrované výuky českého jazyka je propojení jazykové a komunikační složky, jejich chápání jako vzájemně provázaného, a proto neoddělitelného celku. Jen tak poznávání jazyka slouží rozvoji komunikačních dovedností žáka.

Budeme-li uvažovat o oborové didaktice mateřského jazyka jako o interdisciplinárním vědním oboru, který je v úzké 
vazbě $\mathrm{k}$ lingvistice, nicméně rovněž usiluje o vymezení svého vlastního badatelského pole (srov. Slavík \& Šmejkalová, 2016; Šmejkalová, 2015a; Štěpáník, 2019a, s. 13-14), musí dle mého názoru oborová didaktika a výuka mateřštiny při uchopování jazyka vycházet z komunikace, nebot právě v ní se jazyk jako komunikační prostředek realizuje a „zhmotňuje“. V tomto smyslu se perspektiva didaktiky češtiny a následně výuky obrací: základem pro uvažování o formování učebního prostředí mateřského jazyka je $\mathrm{z}$ obecného pohledu komunikace, komunikační potřeba žáka jako každodenního uživatele jazyka, funkce jazykových prostředků v komunikaci, jejich užití a jejich reflexe žáky jako uživateli jazyka. Tím do popředí vystupují disciplíny parolové, tj. ty, které preferují komunikační pohled na zkoumání jazyka - daleko více se proto akcentuje pragmatika, sémantika, sociolingvistika, teorie diskursu, stylistika ad. $\mathrm{V}$ tomto smyslu je naplněno kompetenční zacílení vzdělávání. Systémová (langová) složka je přitom stále př́tomná, avšak jako sekundární, jako rovina konceptuální, v níž je rovina kompetenční ukotvená (srov. Slavík et al., 2017).

Jako spojnici psychodidaktické a ontodidaktické perspektivy a kognitivního a komunikačního cíle jazykové výuky je třeba postavit výuku jazyka jiného typu než typu tradičního (vědeckého) - takovou, která $\mathrm{v}$ sobě bude integrovat perspektivu oboru i žáka a poznávací i komunikační cíl a bude akcentovat komunikačně-pragmaticko-sémantická hlediska.

Školní výuka mateřštiny zahrnuje různé oblasti poznání jazyka, v anglicky psané literatuře se proto užívá termín knowledge about language. $V$ české tradici překlad termínu (znalosti o jazyce) zaveden není, příp. by mohl být chápán jednostranně, pro jazykovou složku se ve školské praxi užívá termín mluvnice. Ten je však zatížen negativní konotací (evokuje správnost a nesprávnost, představu chyby, v českém prostředí spisovnost), navíc může být chápán jako prostě synonymní k termínu gramatika, který svým možným úzkým vymezením (pouze morfologie a syntax) nepokrývá rozsah veškerého jazykového učiva.

$\mathrm{S}$ odkazem na V. Šmilauera (Nauka o českém jazyku; 1. vyd. 1972), jenž se právě z těchto důvodů vyhýbá názvu mluvnice (srov. též Šmejkalová, 2015b), ale prritom prrináší systematické pojednání o systému češtiny v oblasti morfologie, syntaxe, slovotvorby, lexikologie, fonetiky i pravopisu, novou vznikající koncepci výuky českého jazyka nazývám naukou, přičemž jako zdůraznění její praktické komunikační povahy užívám přívlastek komunikační. Vzniká komunikační nauka o českém jazyku. ${ }^{20}$

\footnotetext{
${ }^{20}$ Blízká mému pojetí se zdá být pedagogická gramatika, etablovaná v didaktice cizích jazyků (srov. Hrdlička, 2009; Niesporek-Szamburska, 2019). Ta se vymezuje jako vědecká mluvnice uzpůsobená didaktickým potřebám (Hrdlička, 2009, s. 31). Takové určení pedagogické gramatiky se mi však jeví jako nedostatečné, nebot v mém chápání je didaktický pohled akcentován v tom smyslu, že obsah nejenže slouží didaktickým cílům, ale je jim podřizen. To prakticky znamená, že didaktické cíle mají vliv nejen na způsob didaktického zprostředkování obsahu, ale také na sám výběr obsahu jazykové výuky.
} 


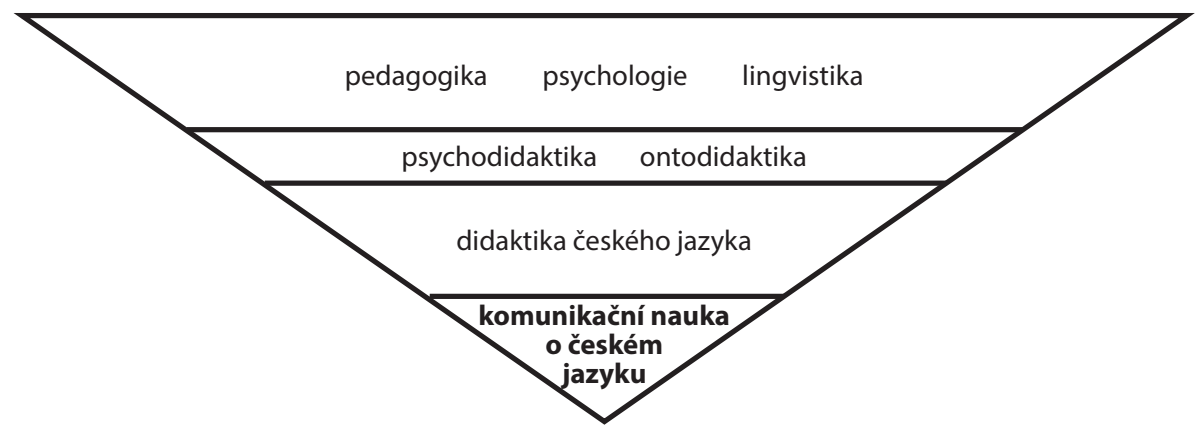

Obr. 1. Zdroje a postavení komunikační nauky o českém jazyku

Zdroji komunikační nauky o českém jazyku jsou v základě vědy o vzdělávání a výchově a oborové (tj. lingvistické) poznání. Z hlediska lingvistických východisek je však podstatné, že nejde jen o paradigma systémově-strukturní, ale též komunikačně-pragmatické, kognitivní, korpusové, funkční atd. Tyto zdroje se následně didaktizují prizmatem psychodidaktiky a ontodidaktiky, přičemž z propojení jejich poznatků následně čerpá oborová didaktika českého jazyka a dále je zpracovává didaktickou rekonstrukcí. Z moderní oborové didaktiky českého jazyka pak vyrůstá komunikační nauka o českém jazyku, v rámci níž je utvářeno učební prostředí (obr. 1).

Vzhledem k tomu, že komunikační nauka o českém jazyku je orientovaná aplikačně (a má tedy specifické cíle), může být co do výběru obsahu eklektická. Výběr jazykových jevů se provádí na základě různých parametrů, ev. jejich kombinace: formální náročnosti učiva, frekvence jazykového jevu v komunikaci, úrovně kognitivního a jazykového vývoje žáků, komunikačních potřeb žáků atd. (srov. Hrdlička, 2009, s. 31). Komunikační nauku o českém jazyku tak lze chápat jako praktickou mluvnici realizující cíle výuky, zahrnující a podmiňující výběr učiva, metody a formy práce ve výuce a následně také vzdělávání učitelů, tvorbu učebnic a jiných učebních pomůcek a obecně přemýšlení učitelů, ale i žáků, rodičủ a vủbec široké veřejnosti o úlohách a podobě výuky mateřského jazyka.

\section{ZÁKLADNÍ CHARAKTERISTIKY KOMUNIKAČNÍ NAUKY \\ O ČESKÉM JAZYKU}

Komunikační nauka o českém jazyku je založena na základním paradigmatu, jež lze vystihnout jako postup od komunikace $\mathbf{k}$ jazyku a zpět. Komunikace nachází ve výuce realizaci v komunikátu (textu - psaném i mluveném), v němž lze nalézt vše, co by mělo 
být předmětem funkční jazykové výuky: komunikační situace, účastníci komunikace a jejich charakteristiky, komunikační záměry a funkce komunikátu, forma a volba jazykových prostředků, různé kódy, normy, žánry atd. Výuka postupuje tak, že jazykový prostředek užitý v konkrétním komunikátu je v kontextu komunikátu ohledán (tím, že je primárně zkoumána funkce, přirozeně dochází k evokaci žákova jazykového prekonceptu a jeho zkušenosti s užitím daného jazykového prostředku), kromě funkce jsou k poznání dodány další kvality (včetně metajazyka) a následně je daný jazykový prostředek (již jako součást poučeného jazykového vědomí) dalším užitím, at už v rovině recepce či produkce, do komunikace vrácen. Jazyk a znalost o jazyku tedy nikdy ve výuce nevystupují samy o sobě.

Základním charakterem nabývaných jazykových znalostí (at už přímo jazyka nebo o jazyce) je jejich přetavení do dovedností, funkční gramotnosti. Jazyková cvičení $\mathrm{v}$ takovém pojetí slouží k hledání co nejlepších jazykových řešení $\mathrm{k}$ realizaci komunikačního záměru a vhodného jazykového chování (Mrazek, 1998, s. 7). Cílem je ovládnutí jak deklarativní, tak i procedurální znalosti - nejen vědět že, ale také vědět jak (srov. Dolník, 2005, s. 41) a proč, čímž se usiluje o překonání dosavadního substančního př́ístupu (srov. Slavík et al., 2017, s. 20-21). Základní se stává efekt, nikoli nutně jazyková správnost - správné není jen to, co je systémové, ale co je adekvátně užito $\mathrm{v}$ reálné komunikaci
(Szymańska, 2016, s. 165). Pozornost se přesouvá od správnost $\mathrm{k}$ vhodnosti, resp. adekvátnosti užití (což se pochopitelně netýká pravopisu a některých oblastí gramatiky). Znalosti o jazyce (metajazykové znalosti) nebrzdí přirozený rozvoj jazyka dítěte, ale jdou přirozeně s ním, poznávání jazyka nepodrývá jazykové sebevědomí jedince, naopak rozvíjí jeho jazykovou kreativitu.

Př́stup v komunikační nauce o českém jazyku lze charakterizovat jako (a) kognitivně-komunikační a (b) konstruktivistický.

Kognitivně-komunikační př́stup je rozpracován $\mathrm{v}$ didaktice slovenštiny (Liptáková et al., 2011; Liptáková, 2012), jeho základním východiskem je integrace kognitivních a komunikačních cílů. Neoddělitelně propojuje pohled jazykový (resp. jazykovědný) a pohled komunikační na určitý jazykový fenomén jako předmět výuky. Př́stup komunikační nauky o českém jazyku není agramatický. Rozvoj poučeného jazykového vědomí a komunikačních dovedností v jeho rámci se opírá o vědomé pozná(vá)ní fungování systému jazyka. Jazykové poznatky však vždy mají komunikační vyústění.

Konstruktivismus je základním proudem didaktických inovací současnosti a rovněž zdrojem nové (produktivní) kultury vyučování a učení (Janík, 2013; Janík et al., 2013). Zahraniční výzkumy ukazují, že efektivní postupy výuky mateřského jazyka jsou založeny na konstruktivistických principech, jsou vysoce textocentrické, kladou důraz na aktivitu žáka, jeho komunikační po- 
třeby, vycházejí z žákových prekonceptů jazykových fenoménů a fungování jazykového systému a především zasazují poučení o jazyce do komunikačně-funkčního rámce, a to nejen analyticky, ale též produkčně (Štěpáník, 2019a, s. 12; shrnutí mezinárodních výzkumů viz in Klimovič, 2019).

Vlastnosti výuky mateřského jazyka pojaté dle teorie komunikační nauky o českém jazyku - a zároveň atributy kognitivně-komunikačního a konstruktivistického modelu výuky pro praxi - tak lze shrnout do následujících bodů (dle Štěpáník \& Šmejkalová, 2017, s. 305):

- Veškerá činnost ve výuce je orientovaná směrem k žákovi, jeho osobnosti, jeho (komunikačním) potřebám.

- Výuka je založená na žákovském prekonceptu.

- Veškerý obsah má komunikační přesah.

- Obsah je vztažen k reálnému každodennímu životu žáka.

- Výuka vychází z živých komunikátů, z reálné komunikace.

- Daleko více je akcentována produkce, a to nejen psaných, ale i mluvených komunikátů.

- Výuka je vedena více $k$ deskripci a funkcionalizaci než preskripci; poznání jazyka je chápáno jako nástroj pro zlepšení komunikace.

- Výuka jazyka je orientovaná (a) sociálně - jazyk, resp. komunikát jsou vnímány jako společenský fenomén - a (b) kognitivně - jazyk, resp. komunikát je rovněž vnímán jako individuální fenomén, jako prostředek interpretace světa, formování postojů a hodnot.
Základním systémovým východiskem komunikační nauky o českém jazyku je teorie komunikačních sfér (nejnověji zpracovaná $\mathrm{v}$ monografii $\mathrm{k}$ stylistice češtiny Hoffmannové et al., 2016; dřive použitá in Jedlička, Formánková \& Rejmánková, 1970), jež odkazuje $\mathrm{k}$ funkčním aspektům, jak je definoval B. Havránek a Pražský lingvistický kroužek. Současná teorie komunikačních sfér klade důraz na aktuální verbální komunikaci (komunikáty určené současnými komunikačními potřebami a postoji $\mathrm{k}$ jazyku) a funkci textů; rozsah výuky českého jazyka se v tomto směru s dynamickými proměnami komunikace, jak je v současnosti zažíváme, rozšiřuje. Jazyk vystupuje jako sociální fenomén, komunikační sféry lze do určité míry ztotožnit se sférami sociálními (Hoffmannová et al., 2016, s. 15). I proto by ve výuce měla být výrazně akcentována problematika stylotvorných faktorů, nebot' ty determinují styl a tím i užité jazykové prostředky.

Chceme-li učinit psychodidaktickou perspektivu jedním ze zdrojů oborové didaktiky češtiny a budeme-li považovat žákovský prekoncept za konstitutivní prvek výuky mateřského jazyka, je nutné nejprve důkladně poznat vývoj a stav dětské řeči v různých vývojových fázích, nebot' bez něj „komunikační model vyučování mateřského jazyka zůstane spíše proklamovanou než realizovanou představou, víc parciální a příležitostní metodou než promyšleným a systematickým př́stupem, směřujícím $k$ přeměně spontánního jazykového vědomí dítěte na poučené, reflexivní a kultivované jazykové vědomí" 
(Kesselová, 2001, s. 7). Širokým tématem pro didaktiku českého jazyka ve spojení s psycholingvistikou a kognitivní lingvistikou se tak stává zkoumání, jak dochází k rozvoji jazyka a jazykových dovedností žáka (provázaně s komunikačními dovednostmi), jak se rozvíjí žákovo myšlení o jazyce a v jazyce a jak výuka může $\mathrm{k}$ rozvoji takového myšlení, tzn. k rozvoji jazykového vědomí, přispět. $V$ tomto ohledu jsou pro nás vysoce inspirující práce slovenské (Kapalková et al., 2010; Kesselová, 2001, 2003; Liptáková \& Vužňáková, 2009; Ondráčková, 2010; Slančová, 1999, 2008, 2018), české práce nejsou tak četné, avšak i u nás zásadně vzrostl zájem o poznání jazykového prekonceptu žáků (napřr. Hájková et al., 2013, 2014, 2015; Štěpáník, 2014b; Štěpáník \& Slavík, 2017) a o podoby a procesy osvojování jazyka dítětem (např. Bytešníková, 2012; Chejnová, 2016a, b, 2017; Průcha, 2011; Saicová Římalová, 2013, 2016; Smolík, 2007; Smolík \& Seidlová Málková, 2014). I nadále výzkum jazykových prekonceptů a řeči dítěte představuje pro oborovou didaktiku češtiny široké téma $\mathrm{k}$ řešení.

\section{ZÁVĚR}

V historii oborové didaktiky českého jazyka najdeme zlomové okamžiky, které měly za cíl revidovat postavení mluvnice $\mathrm{v}$ jazykové výuce, $\mathrm{z}$ různých důvodů se však zásadní transformace výběru obsahu a práce s obsahem neuskutečnila. Disku- se řešily (a řeší) spíše parametry komunikace a interakce ve výuce, jednotlivé metody a formy práce, možnosti redukce učiva (nikoli jeho kvalitativní rozměr) apod. Problémy, v nichž se výuka češtiny na základní a střední škole nachází, jsou však daleko hlubší. Především jde totiž o potíže v celkovém pojetí výuky. Řešení proto musejí být na úrovni utváření celého didaktického systému. Z toho vyplývá, že se nelze spokojit pouze $s$ nějakým parciálním řešením, potřebný je faktický a radikální obrat didaktické perspektivy. Východiskem se musí stát komunikace (v konkrétních komunikačních situacích, při vyjadřování konkrétních významů a záměrů). Uvažuji $\mathrm{v}$ intencích transdidaktického př́stupu, který umožňuje efektivně didakticky nahlédnout obsah výuky, pochopit jeho didaktický potenciál a na základě toho jej pak pro výuku funkčně rekonstruovat. Cílem je celková změna perspektivy na výuku jazyka a o jazyku v tom smyslu, jak může její explicitní výuka pomoci žákům při rozvoji jejich komunikačních dovedností, jak může pomoci žákům při produkci i recepci určitého komunikátu. Jedině tak se žák stane komunikačně a jazykově kompetentní.

$\mathrm{O}$ zmíněnou proměnu usiluje právě komunikační nauka o českém jazyku, kterou jsem $\mathrm{v}$ tomto př́íspěvku stručně představil a jež bude předmětem didaktické monografie Školni výpravy do krajiny češtiny: Didaktika českého jazyka pro základni školu. 


\section{Literatura}

Andrews, R. et al. (2006). The effect of grammar teaching on writing development. British Educational Research Journal, 32(1), 39-55.

Bakuła, K. (2014). Świadomość językowa - świadomość dydaktyczna. In J. Nocoń \& A. Tabisz (Eds.), Język a edukacja: Świadomość jezzykowa (s. 37-52). Opole: Wydawnictwo Uniwersytetu Opolskiego.

Bytešníková, I. (2012). Komunikace dètí prèedškolniho věku. Praha: Grada.

Čechová, M. (1998). Komunikační a slohová výchova. Praha: ISV.

Čechová, M. (2011/2012). Zrušíme nejen větné rozbory? Český jazyk a literatura, 62(5), 237-241.

Čechová, M., \& Styblík, V. (1998). Čě́tina a její vyučování. Praha: SPN.

Čermák, F. (2004). Jazyk a jazykovéda. Praha: Karolinum.

Čmejrková, S., \& Hoffmannová, J. (Eds.). (2011). Mluvená čeština: hledáni funkčního rozpètí. Praha: Academia.

ČŠI. (2019). Rozvoj čtenárské gramotnosti na základnich a střednich školách ve školnim roce 2017/2018. Praha: Česká školní inspekce.

Derewianka, B., \& Jones, P. (2010). From traditional grammar to functional grammar: bridging the divide. NALDIC Quarterly, 8(1), 6-17.

Dolník, J. (2003). Jazykové sebavedomie. Slovenská reč, 68(5), 1-14.

Dolník, J. (2005). Jazykový systém ako kognitívna realita. In J. Rybár, V. Kvasnička \& I. Farkaš (Eds.), Jazyk a kognicia (s. 39-83). Bratislava: Kalligram.

Duit, R., Gropengießer, H., Kattmann, U., Komorek, M., \& Parchmann, I. (2012). The model of educational reconstruction - a framework for improving teaching and learning science. In D. Jorde \& J. Dillon (Eds.), Science education research and practice in Europe: Retrospective and prospective (s. 13-37). Rotterdam: Sense Publishers.

Dyduchowa, A. (1988). Metody ksztatcenia sprawności językowej uczniów: projekt systemu, model podręcznika. Kraków: Wydawnictwo Naukowe WSP.

Fearn, L., \& Farnan, N. (2007). When is a verb? Using functional grammar to teach writing. Journal of Basic Writing, 26(1), 1-26.

Fogel, H., \& Ehri, L. C. (2000). Teaching elementary students who speak black English vernacular to write in Standard English: Effects of dialect transformation practice. Contemporary Educational Psychology, 25(2), 212-235.

Gombert, J. E. (1992). Metalinguistic development. Chicago: University of Chicago Press.

Hájková, E. (2009). Komunikační činnosti a jejich cíle. Praha: Pedagogická fakulta Univerzity Karlovy.

Hájková, E. (2013). Učivo o větě na 1. stupni. Didaktické studie, 5(2), 11-19.

Hájková, E., Hejlová, H., Janovec, L., Kucharská, A., Babušová, G., \& Höflerová, E. (2013). Čeśtina ve škole 21. století - III. Jazykové jevy v dètských prekonceptech. Praha: Pedagogická fakulta Univerzity Karlovy. 
Hájková, E., Hejlová, H., Janovec, L., Kucharská, A., Babušová, G., \& Höflerová, E. (2014). Čeština ve škole 21. století - IV. Výzkum edukačnich podminek jazykových jevů. Praha: Pedagogická fakulta Univerzity Karlovy.

Hájková, E., Hejlová, H., Janovec, L., Kucharská, A., Babušová, G., \& Höflerová, E. (2015). Czech language in the $21^{s t}$ century school $-V$. Children's preconceptions within the educational framework of Czech language. Praha: Pedagogická fakulta Univerzity Karlovy.

Hoffmannová, J., Homoláč, J., Chvalovská, E., Jílková, L., Kaderka, P., Mareš, P., \& Mrázková, K. (2016). Stylistika mluvené a psané céstiny. Praha: Academia.

Höflerová, E. (2015). Constructivism in teaching the mother tongue or how to teach the Czech language better to Czech-speaking children. Pedagogika, 65(5), 532-541.

Horecký, J. (1991). Jazykové vedomie. Jazykovedný časopis, 42(2), 81-88.

Hrdlička, M. (2009). Gramatika a výuka češtiny jako cizího jazyka. Praha: Karolinum.

Chejnová, P. (2016a). Acquisition of morphological categories and vocabulary in early ontogenesis of a Czech child. Praha: Karolinum.

Chejnová, P. (2016b). Osvojování gramatických kategorií sloves u českého dítěte. Slovo a slovesnost, 77(3), 185-201.

Chejnová, P. (2017). Acquisition of adverbs and pronominal adverbs in a Czech child. Topics in Linguistics, 18(1), 32-47.

Chvál, M., \& Šmejkalová, M. (2018). Řešení úloh z české syntaxe žáky 4.-9. ročníků základních škol. Studia paedagogica, 23(1), 106-134.

Janík, T. (2013). Od reformy kurikula k produktivní kultuře vyučování a učení. Pedagogická orientace, 23(5), 634-663.

Janík, T. et al. (2013). Kvalita (ve) vzdèláváni: obsahově zaměrèný prístup ke zkoumáni a zlepšováni výuky. Brno: Masarykova univerzita.

Janík, T., \& Slavík, J. (2009). Obsah, subjekt a intersubjektivita v oborových didaktikách. Pedagogika, 59(2), 116-135.

Janík, T., Maňák, J., \& Knecht, P. (2009). Cíle a obsahy školního vzdèláváni a metodologie jejich utvárení. Brno: Paido.

Jedlička, A., Formánková, V., \& Rejmánková, M. (1970). Základy českéstylistiky. Praha: SPN. Jelemenská, P., Sander, E., \& Kattmann, U. (2003). Model didaktickej rekonštrukcie: impulz pre výskum v odborových didaktikách. Pedagogika, 53(2), 190-201.

Jelínek, J. (1972). Nástin dèjin vyučování českému jazyku. Praha: SPN.

Jelínek, J. (1980). Úvod do teorie vyučování českému jazyku. Praha: SPN.

Jones, S., Myhill, D., \& Bailey, T. (2013). Grammar for writing? An investigation of the effects of contextualised grammar teaching on students' writing. Reading and Writing, 26(8), 1241-1263.

Kapalková, S. et al., (2010). Hodnotenie komunikačných schopností detí v ranom veku-s testami a normami. Bratislava: Slovenská asociácia logopédov.

Kesselová, J. (2001). Lingvistické štúdie o komunikácii detí. Prešov: Náuka. 
Kesselová, J. (2003). Morfológia v komunikácii detí. Prešov: Vydavatel'stvo Anna Nagyová. Klimovič, M. (2016). Detský pisatel'v procese tvorby textu. Prešov: Prešovská univerzita v Prešově. Klimovič, M. (2019). Komunikačně-funkční pojetí výuky mateřského jazyka v širším mezinárodním kontextu. In S. Štěpáník et al., Vztah jazyka a komunikace v česko-slovensko-polské didaktické reflexi (s. 72-87). Praha: Karolinum.

Knecht, P. (2007). Didaktická transformace anebo Od „didaktického zjednodušení k „didaktické rekonstrukci“. Orbis scholae, 2(1), 67-81.

Komorek, M., \& Kattmann, U. (2008). The model of educational reconstruction. In S. Mikelskis-Seifert, U. Ringelband \& M. Brückmann (Eds.), Four decades of research in science education - from curriculum development to quality improvement (s. 171-188). Münster: Waxmann.

Kotenová, M. (2018/2019). Je komunikačně orientovaná výuka skladby nedostižnou metou? Český jazyk a literatura, 69(2), 59-66.

Liptáková, L. (2012). Kognitivne aspekty vyučovania materinského jazyka v primárnej edukácii. Prešov: Pedagogická fakulta Prešovské univerzity v Prešově.

Liptáková, L. (2013). O vztahu a šstruktúre implicitných a explicitných jazykových znalostí dietata mladšieho školského veku. O dietati, jazyku, literatúre, 1(2), 15-30.

Liptáková, L. et al. (2011). Integrovaná didaktika slovenského jazyka a literatúry pre primárne vzdelávanie. Prešov: Pedagogická fakulta Prešovské univerzity v Prešově.

Liptáková, L., \& Vužňáková, K. (2009). Dieta a slovotvorba. Prešov: Pedagogická fakulta Prešovské univerzity v Prešově.

Metz, M. (2018). Pedagogical content knowledge for teaching critical language awareness: The importance of valuing student knowledge. Urban Education, 45, 1-29.

Mrazek, H. (1998). Komunikacyjny model nauczania. Rozwijanie języka dziecka w klasach IV-VIII. Umiejętności i wiedza. Nowa Polszczyzna, 1, 3-8.

Myhill, D. (2005). Ways of knowing: Writing with grammar in mind. English Teaching: Practice and Critique, 4(3), 77-96.

Myhill, D. (2016). The effectiveness of explicit language teaching: Evidence from the research. In M. Giovanelli \& D. Clayton (Eds.), Knowing about language (s. 36-47). London: Routledge.

Myhill, D. (2018). Grammar as a meaning-making resource for improving writing. L1Educational Studies in Language and Literature, 18, 1-21.

Myhill, D. et al. (2011). Grammar for writing? The impact of contextualised grammar teaching on pupils' writing and pupils' metalinguistic understanding: ESRC end of award report, RES-062-23-0775. Swindon: ESRC. (Online). Dostupné z https://www.researchcatalogue.esrc.ac.uk.

Myhill, D., Jones, S., Lines, H., \& Watson, A. (2012). Re-thinking grammar: The impact of embedded grammar teaching on students' writing and students' metalinguistic understanding. Research Papers in Education, 27(2), 1-28. 
Niesporek-Szamburska, B. (2019). Výuka o jazyce pro učení se jazyku aneb Které znalosti o jazyce vyučovat a jak je zprostředkovat žákům. In S. Štěpáník et al., Vztah jazyka a komunikace v česko-slovensko-polské didaktické reflexi (s. 120-131). Praha: Karolinum.

Nocoń, J. (2010). Uczenie o języku polskim po 1998 roku - programy i koncepcje dydaktyczne. In J. Nocoń \& E. Łucka-Zając (Eds.), Uczeń w świecie języka i tekstów (s. 27-37). Opole: Wydawnictwo Uniwersytetu Opolskiego.

Nocoń, J. (2018). Lingwodydaktyka na progu XXI wieku. Konteksty - Koncepcje - Dylematy. Opole: Wydawnictwo Uniwersytetu Opolskiego.

Ondráčková, Z. (2010). Komparativny výskum detskej lexiky. Prešov: Filozofická fakulta Prešovské univerzity v Prešově.

Palek, B. (1989). Základy obecné jazykovédy. Praha: SPN.

Pavelková, I. (2013). Postoje žáků k českému jazyku a jejich percepce učiteli. Didaktickéstudie, 5(1), 27-45.

Průcha, J. (2011). Détská réč a komunikace. Praha: Grada.

Pupala, B., \& Osuská, L. (2000). Vývoj, podoby a odkazy teórie konštruktivizmu. Pedagogická revue, 52(2), 101-114.

Reich, K. (2012). Konstruktivistische Didaktik. Basel: Beltz.

Saicová Římalová, L. (2013). Když začináme mluvit... Lingvistický pobled na rané projevy česky hovorícího ditète. Praha: Filozofická fakulta Univerzity Karlovy.

Saicová Ř́malová, L. (2016). Osvojování jazyka ditétem. Praha: Karolinum.

Shulman, L. S. (1987). Knowledge and teaching: Foundations of the new reform. Harvard Educational Review, 57(1), 1-22.

Slančová, D. (1999). Reč autority a lásky: reč učitellky materskej školy orientovaná na dietáa - opis registra. Prešov: Filozofická fakulta Prešovské univerzity v Prešově.

Slančová, D. (2008). (Ed.). Štúdie o detskej rečí. Prešov: Filozofická fakulta Prešovské univerzity v Prešově.

Slančová, D. (2018). (Ed.). Desat štúdii o detskej reči. Prešov: Filozofická fakulta Prešovské univerzity v Prešově.

Slavík, J., \& Janík, T. (2005). Významová struktura faktu v oborových didaktikách. Pedagogika, 55(4), 336-353.

Slavík, J., \& Šmejkalová, M. (2016). K pojetí didaktiky českého jazyka jako vědecké disciplíny. Studie $z$ aplikované lingvistiky, 7(1), 111-120.

Slavík, J., Janík, T., Najvar, P., \& Knecht, P. (2017). Transdisciplinární didaktika: o učitelském sdíleni znalostí a zvyšováni kvality výuky napríć obory. Brno: Masarykova univerzita.

Smith, M., Cheville, J., \& Hillocks, G. (2006). „I guess I’d better watch my English“: Grammar and the teaching of English language arts. In C. MacArthur, S. Graham \& J. Fitzgerald (Eds.), Handbook of writing research (s. 263-274). New York: Guilford Press.

Smolík, F. (2007). Teoretické přistupy k osvojováni gramatiky. Hradec Králové: Gaudeamus. 
Smolík, F., \& Seidlová Málková, G. (2014). Vývoj jazykových schopností v predškolním věku. Praha: Grada.

Svalberg, A. M.-L. (2007). Language awareness and language learning. Language Teaching, 40(4), 287-308.

Svobodová, J. (2003). Jazyková specifika školské komunikace a výuka mateřstiny. Ostrava: Ostravská univerzita.

Svobodová, J., Adámková, I., Bogoczová, I., Jandová, E., Metelková Svobodová, R., \& Svobodová, D. (2011). Fenomén spisovnosti v současné české jazykové situaci. Ostrava: Ostravská univerzita. Szymańska, M. (2016). Między nauka o języku a rozwijaniem języka. Koncepcje ksztatcenia językowego na przetomie XX i XXI wieku. Kraków: Wydawnictwo Naukowe UP.

Šalamounová, Z. (2013). Výuková situace: Když spojky nejen spojují aneb Ke komunikačnímu pojetí výuky gramatiky. Komenský, 137(3), 38-44.

Šalamounová, Z. (2015). Socializace do školního jazyka. Brno: Filozofická fakulta Masarykovy univerzity.

Šebesta, K. (2005). Od jazyka ke komunikaci: didaktika českého jazyka a komunikačni výchova. Praha: Karolinum.

Šmejkalová, M. (2010). Čeština a škola - úryvky skrytých dějin. Praha: Karolinum.

Šmejkalová, M. (2015a). Didaktika českého jazyka. In I. Stuchlíková \& T. Janík et al. (Eds.), Oborové didaktiky: vývoj-stav-perspektivy (s. 17-40). Brno: Masarykova univerzita.

Šmejkalová, M. (2015b). Praporu véren i ve ztraceném boji: Vladimir Šmilauer-život a dílo filologa (1895-1983). Praha: Academia.

Šmilauer, V. (1972). Nauka o českém jazyku. Praha: SPN.

Štěpáník, S. (2014a). Konstruktivismus ve výuce českého jazyka na strední škole. Nepublikovaná disertační práce. Praha: Pedagogická fakulta Univerzity Karlovy.

Štěpáník, S. (2014b). Příklad výzkumu žákovských představ v české syntaxi. Pedagogická orientace, 24(1), 111-127.

Štěpáník, S. (2015). Konstruktivismus a jeho didaktické implikace ve vyučování českého jazyka. Nová čeśtina doma a ve svétě, 2, 11-22.

Štěpáník, S. (2016). Výuková situace: Transformace větného členu na větu a naopak v kontextu větného rozboru. Komenský, 140(4), 30-39.

Štěpáník, S. (2018). Vliv nové podoby maturitní zkoušky z českého jazyka a literatury na vyučování ve výpovědích učitelů. Pedagogická orientace, 28(3), 435-471.

Štěpáník, S. (2019a). Výuka mluvnice ve vztahu k rozvoji komunikačních dovedností - úvod do problému. In S. Štěpáník et al., Vztah jazyka a komunikace v česko-slovensko-polské didaktické reflexi (s. 7-22). Praha: Karolinum.

Štěpáník, S. (2019b). Kognitivně-komunikační princip jako základní východisko výuky českého jazyka. Ceský jazyk a literatura, 69(5), 214-223.

Štěpáník, S., Hájková, E., Eliášková, K., Liptáková, L., \& Szymańska, M. (2020). Školni výpravy do krajiny češtiny: Didaktika českého jazyka pro základni školy. Plzeň: Fraus. 
Štěpáník, S., \& Chvál, M. (2016). Konstruktivismus jako cesta ke zlepšování výsledků vzdělávání v českém jazyce? Studia paedagogica, 21(1), 35-56.

Štěpáník, S., \& Slavík, J. (2017). Žákovské prekoncepty jako konstitutivní prvek výuky mateřského jazyka. Pedagogická orientace, 27(1), 58-80.

Štěpáník, S., \& Šmejkalová, M. (2017). Prưvodce začinajicího češtináré. Praha: Pedagogická fakulta Univerzity Karlovy.

Štěpáník, S., Liptáková, L., \& Szymańska, M. (2019). Cesty ke komunikačně-funkčnímu pojetí v české, slovenské a polské didaktice mateřského jazyka. In S. Štěpáník et al., Vztah jazyka a komunikace v česko-slovensko-polské didaktické reflexi (s. 23-71). Praha: Karolinum.

Štěpáník, S. et al. (2019). Vztah jazyka a komunikace v česko-slovensko-polské didaktické reflexi. Praha: Karolinum.

van Dijk, E., \& Kattmann, U. (2007). A research model for the study of science teachers' PCK and improving teacher education. Teaching and Teacher Education, 23(6), 885-897. Wyse, D. (2001). Grammar for writing? A critical review of empirical evidence. British Journal of Educational Studies, 49(4), 411-427.

Zimová, L. (2011/2012). O potřebnosti větného rozboru. Českýjazyk a literatura, 62(5), 241-244.

PhDr. Stanislav Štépánik, Ph.D.

Pedagogická fakulta Univerzity Karlovy, Katedra českého jazyka;

e-mail: stanislav.stepanik@pedf.cuni.cz

\section{ŠTĚPÁNÍK, S. A Constructivist and Cognitive-Communicative Paradigm as the Basis of the Conception of Czech Language Instruction}

The theoretical study deals with the problem of creating a learning environment which determines the quality of Czech language (L1) instruction. The elaboration of the problem is grounded in the integration of the semantic-logical structure of the content interconnecting the language and the communicative components of the subject. First, the study describes the general theories of the current state of Czech instruction, with a special focus on the relation between the scientific field (linguistics) and the school subject (or instruction). Next, it analyses the difficulties which the existing conception of Czech language instruction creates, and it scrutinises their causes. The problem is viewed from the perspective of both transdisciplinary didactics and disciplinary didactics of Czech language teaching. Finally, as a solution, the paper puts forward an innovative conception of Czech language instruction called Communicative Teaching about Czech Language, defines its sources and specifies its programme.

Keywords: transdisciplinary didactics, Czech language didactics, Czech language, conception of instruction, Communicative Teaching about Czech language, constructivism, tradition, innovation. 